\title{
Bartleby i Michael K., czyli dlaczego tylko mężczyzna może stać się innym?
}

\section{Joanna Bednarek}

badaczka niezależna

\begin{abstract}
[Artkuł ukazał się wcześniej na łamach InterAliów w sekcji artykuły bieżące, tutaj.]
Wiele już napisano na temat stworzonej przez Hermana Melville'a postaci Bartleby'ego - najczęściej interpretując stynne "wolatbym nie" jako różnie pojmowana formę politycznego lub pre-politycznego oporu. Tę lawinę tekstów zapoczątkowat, o czym się czasem zapomina, esej Gilles'a Deleuze'a "Bartleby albo formuta”, którego centralnym motywem jest nie opór, ale stawanie-się-innym: proces oddalania się od dominującego, większościowego wzorca męskiej, europejskiej, kapitalistycznej i edypalnej tożsamości. Procesowi temu może jednak podlegać tylko wspomniany większościowy podmiot: inny, dzięki któremu możliwe jest stawanie się, petni wytącznie funkcje pomocnicza czy instrumentalna: w przypadku tekstu Melville'a, to bezimienny narrator, a nie Bartleby, jest jego prawdziwym bohaterem. Stawanie się jest więc przygoda zarezerwowana dla podmiotu większościowego. Deleuze wydaje się jednak nie zdawać sobie sprawy z tego ograniczenia. Tekst Coetzee'ego ukazuje natomiast, na przykładzie skazanej na porażkę relacji między tytułowym bohaterem a próbujacym go "zrozumieć" lekarzem, asymetrię dwóch terminów stawania się i podporządkowanie innego, a tym samym dekonstruuje hierarchię zawarta w pojęciu stawania się.
\end{abstract}

Słowa kluczowe: stawanie się, Deleuze i Guattari, Bartleby, Coetzee

Postać Bartleby'ego, stworzona w 1853 roku przez Hermana Melville'a, doczekała się pod koniec XX wieku niezwykłej sławy: poświęcono jej szereg interpretacji filozoficznych, najczęściej skupiających się na słynnej formule "wolałbym nie" jako różnie pojmowanej formie politycznego bądź pre-politycznego oporu wobec władzy. Tą drogą podążają w swoich odczytaniach opowiadania Melville'a - czy raczej nieco węższych próbach zinterpretowania samego motywu Bartleby'ego - Giorgio Agamben, Slavoj Žižek czy Antonio Negri i Michael Hardt'. U źródeł wspomnianej popularności Bartleby'ego znajduje się jednak odczytanie znacznie mniej redukcyjne, bliższe tekstowi Melville'a esej Gilles'a Deleuze'a „Bartleby albo formuła” z 1989 roku.

Deleuze, zamiast ograniczać się do samej postaci Bartleby'ego, podkreśla fakt, że o dynamice opowiadania stanowią relacje między ekscentrycznym kopistą a zatrudniającym go adwokatem - pierwszoosobowym narratorem tekstu. Narrator, którego „normalność” i reprezentatywność jako „uniwersalnego" (męskiego, białego, obdarzonego władzą ekonomiczną i symboliczną) podmiotu zostaje podkreślona na samym początku tekstu Melville'a, zawiera z Bartlebym rodzaj paktu, owocującego jego oddaleniem się od symbolicznego centrum. Nie tylko od początku traktuje Bartleby'ego inaczej niż pozostałych pracowników, ale nawet (gdy ten uparcie powtarza wolałbym nie w odpowiedzi na służbowe polecenia), usiłuje go zrozumieć, a potem udzielić mu pomocy (zamiast, jak postąpiłoby większość pracodawców, po prostu wyrzucić go z pracy). Czyni tak, mimo że -

1 Zob. G. Agamben, Bartleby, czyli o przypadkowości (2009); M. Hardt, A. Negri, Imperium (2005), s. 221-222; S. Žižek, Notes Towards a Politics of Bartleby (2006); Jacques Ranciere przedstawia natomiast, wychodząc od tekstu Deleuze'a, krytykę deleuzjańskiej koncepcji powiązania polityki i estetyki; zob. J. Ranciere, Deleuze, Bartleby, and the Literary Formula (2004). 
a może właśnie dlatego że? - nie wydaje się postrzegać go nie tylko jako równego sobie, ale w ogóle jako człowieka; mówi o nim: „dziwne stworzenie” (Melville 2009: 45), „tak samo nieszkodliwy i niezdolny do wydania głosu jak te stare krzesła" (Melville 2009: 46). Ta przejawiająca się w rzucanych mimochodem określeniach „nieludzkość” Bartleby'ego jest kluczem do relacji, jaka łączy go z narratorem. Istotą deleuzjańskiego odczytania nie jest bowiem opór, ale proces stawania-się-mniejszościowym lub stawania-się-innym.

Deleuze i Guattari definiują stawanie się jako eksperymentalny proces - który może być obecny zarówno w wymiarze społecznym, jak w praktykach artystycznych i codziennym doświadczeniu jednostki - oddalania się od dominującego, większościowego wzorca męskiej, europejskiej, kapitalistycznej i edypalnej podmiotowości (Deleuze, Guattari 2008: 320-323). Wiąże się ono z wprowadzonym przez nich odróżnieniem tego, co większościowe i tego, co mniejszościowe, jako odmiennym od podziału na większość i mniejszości. Ten drugi podział odnosi się do statycznych grup istniejących w obrębie społeczeństwa; pierwszy natomiast dotyczy typów organizacji dyskursów, praktyk i funkcjonowania grup i jednostek.

Większościowość jest związana z obecnością pojedynczego centrum, organizującego całe pole społeczno-symboliczne i tym samym wytwarzającego też mniejszości jako pozycje podporządkowane - inne-niż, pozbawione autonomii, usytuowane jako podrzędne (Deleuze, Guattari 2008: 188-189, 196-198). Dlatego też bycie mniejszością nie wystarczy, by stanowić czynnik emancypacyjnych zmian. Prawdziwie rewolucyjne jest dopiero stawanie-się-mniejszościowym - dlatego, jak stwierdzają w kontekście stawania-się-kobietą Deleuze i Guattari „kobiety muszą stać się kobietami” (Deleuze, Guattari 2008: 304). Jak podkreślają autorzy Anti-Oedipus: Capitalism and Schizophrenia, stawanie się nie ma charakteru molowego ${ }^{2}$ - nie polega na naśladowaniu formy czy postaci tego, czym się stajemy - ale na molekularnym zarażeniu się tym, co inne: molekułami inności; na destabilizacji swojej molowej tożsamości poprzez wytworzenie w jej obrębie relacji charakterystycznych dla tego, co inne:

[...] stawanie się polega na wyodrębnieniu cząstek, między którymi ustanawia się takie relacje ruchu i spoczynku, prędkości i powolności, które są najbliższe temu, czym się stajemy, i przez co się stajemy [podkr. J. B]. (Deleuze, Guattari 2008: 300)

W Kopiście Bartlebym rolę wirusa, prowadzącego do minoryzacji zarówno języka, jak i społecznego urządzenia, jakim jest kancelaria, odgrywa nie tylko zachowanie Bartleby'ego, ale także (i głównie) formuła "wolałbym nie": nie do końca poprawna (zamiast: l'd prefer not to w naturalnym, większościowym języku angielskim powiedzielibyśmy: I'd rather not), nie będąca politycznym oporem ani

2 Rozróżnienie molowe-molekularne pojawia się w Anty-Edypie, ale zachowuje istotną pozycję w $A$ Thousand Plateaus. Dotyczy ono różnych typów organizacji zjawisk: wymiar molowy określa formę, tożsamość danego układu, to, czym on "jest" w dość potocznym znaczeniu: na przykład kategorie tożsamościowe, których używamy, określając siebie - wpasowując się w jakąś ogólną kategorię - jak "kobieta”, "mężczyzna”, „uczeń”, „pracownica” itp. - mają charakter molowy. Wymiar molekularny obejmuje z kolei przekształcenia intensywności rozmaitych układów - np. sposób, w jaki doświadczamy własnej płci i seksualności albo wielowymiarową dynamikę kontroli i oporu, wyzysku i sprawczości, przejawiającą się w danym środowisku pracy. Deleuze i Guattari odwołują się tu do pochodzącego z dziedziny chemii rozróżnienia na mol danej substancji (liczba Avogadro substancji, określająca, jak liczba atomów jest potrzebna, by ilość gramów substancji była równa jej masie atomowej) i składające się na nią molekuły; zob. D. Olkowski, After Alice: Alice and the Dry Tail (2008). 
nawet jednoznaczną odmową, enigmatyczna. W ten sposób uruchomiony zostaje proces podążania za linią ujścia, prowadzący do demontażu większościowej tożsamości czy organizacji. Stawanie-sięmniejszościowym ma nie tylko emancypować mniejszości, ale przekształcać całe pole społeczne likwidować samo organizujące je centrum. Istotą tego procesu jest destabilizacja (deterytorializacja $^{3}$ ) tego, co większościowe - tylko dzięki niej pozbywamy się hierarchicznej organizacji.

Fakt, że podejmowane przez adwokata próby przeniknięcia tajemnicy Bartleby'ego są nieodmiennie chybione (Deleuze, Guattari 2008: 100) ${ }^{4}$, a on sam, sfrustrowany i zaniepokojony grożącą mu utratą pozycji społecznej, podejmuje w końcu próby pozbycia się dziwacznego pracownika, tylko potwierdza interpretację francuskiego filozofa. Jak sugeruje deleuzjańska lektura Melville'a, Kopista Bartleby stanowi opis przypadku nieudanego stawania się. Narrator, przerażony perspektywą deterytorializacji, rezygnuje z podążania ścieżką stawania-się-mniejszościowym. Przywołuje na pomoc język filantropii, próbuje traktować Bartleby'ego jako obiekt chrześcijańskiego miłosierdzia, wreszcie ucieka w sensie dosłownym, przenosząc kancelarię pod inny adres:

[...] czy Bartleby prosił o coś innego niż odrobina zaufania ze strony adwokata, który w zamian odpowiadał mu miłosierdziem i filantropią, wszystkimi maskami funkcji ojcowskiej? Jedyna wymówka adwokata jest taka, że pragnie wycofać się z drogi stawania się, na którą Bartleby, swą samotną egzystencją, próbuje go zepchnąć [...]. (Deleuze, Guattari 2009: 101)

Czy jednak jest to tylko przypadek? Czy „zdrada” narratora i porażka deterytorializacji to tylko kwestia nieszczęśliwego wyniku tego jednego, szczególnego procesu? Czy mógłby w jakiś sposób pozostać wierny paktowi zawartemu z Bartlebym? Zdaniem Deleuze'a - prawdopodobnie tak: w eseju stwierdza on, że stawanie się ma prowadzić do stworzenia wspólnoty działającej poza funkcją ojcowską, w oparciu o alians, nie filiację ${ }^{5}$ - wspólnoty bez ojców (realnych, wyobrażeniowych czy symbolicznych), wspólnoty braci (i, w domyśle, sióstr, choć to problematyczne rozstrzygnięcie, świadczące raczej o omijaniu problemu niż jego rozwiązaniu). Tym tropem podąża lan Buchanan w rozdziale swojej pracy Deleuzism poświęconym stawaniu-się-kobietą (Buchanan, 2000). Przytaczając przykłady pochodzące od Deleuze'a (Pierre i Isabelle, rodzeństwo z powieści Melville'a Pierre, Or the Ambiguities, Katarzyna i Heathcliff z Wichrowych Wzgórz) opisuje wspólne stawanie się mężczyzny i kobiety/brata i siostry jako paradygmat wspólnoty opartej na aliansie. Zakłada jako oczywiste, że zarówno proces stawania się, jak i powstająca wspólnota, obejmują i mężczyzn,

${ }^{3}$ Każde urządzenie/maszyna/organizm powstaje w oparciu o terytorium (przestrzenne, dźwiękowe, motoryczne) i funkcjonuje za sprawą tendencji do deterytorializcji (przekształceń, destabilizacji, otwarcia na zewnętrze) i reterytorializacji (zatrzymywania przepływu, ustalenia granic, ustabilizowania tożsamości).

${ }^{4}$ Do takich chybionych prób należy zamykające tekst przytoczenie pogłoski, jakoby Bartleby pracował kiedyś w "biurze martwych listów" - prawdziwa czy nie, stanowi ona tylko atrapę wyjaśnienia, nie dostarczając wskazówek, które byłyby na miarę jego skandalicznego i enigmatycznego zachowania.

${ }^{5}$ Alians i filiacja to terminy użyte w Anti-Oedipus: Capitalism and Schizophrenia do opisu prymitywnej maszyny terytorialnej, jednej z trzech wielkich maszyn społecznych. Filiacja oznacza typ "pionowych", międzypokoleniowych powiązań społecznych, dla których najistotniejsze jest ojcostwo i kwestia pochodzenia. Alians natomiast odnosi się do powiązań „poziomych" między jednostkami należącymi do tego samego pokolenia. w innych tekstach Deleuze'a alians zyskuje sens ogólny, służąc jako określenie wszelkich relacji poziomych, niehierarchicznych, niezapośredniczonych przez znaczące. 
i kobiety, zwyczajnie unieważniając ich molowe usytuowanie w różnych miejscach większościowej hierarchii (zwróćmy uwagę na fakt, że mowa jest o „odmienności”, nie o hierarchii!):

[...] brat i siostra są jednym, mimo iż pozostają różni. Ich odmienność [...] nie jest już natury istotowej, jest czysto funkcjonalna: bardziej wartościowość ${ }^{6}$ niż własność. (Buchanan 2000: 96)

Podobnie miałaby się, jak można wnioskować, sprawa z pozostałymi wyznacznikami inności: płeć, rasa, status społeczny, prawomocność mówienia związana ze zdrowiem psychicznym i „normalnością" przestają mieć znaczenie. Omijanie problemu różnicy seksualnej jako hierarchii, dostrzegalne już w eseju Deleuze'a, tutaj staje się tylko bardziej widoczne. Tym samym docieramy do problemu, związanego z samą strukturą pojęcia stawania się. U podstaw interpretacji Buchanana tkwi założenie, że stawanie się jest procesem, któremu oba terminy podlegają w równym stopniu; innymi słowy, stawanie się jest postrzegane jako wzajemne i symetryczne (Buchanan 2000: 97). Czy kategoria ta, w postaci opracowanej przez Deleuze'a i Guattariego, usprawiedliwia taką interpretację? I czy, tym samym, pozwala pomyśleć stawanie się nie tylko podmiotów umieszczonych w centrum większościowego porządku, ale również podmiotów podporządkowanych, "mniejszości”?

To kluczowy moment; zanim jednak spróbuję odpowiedzieć na zadane przeze mnie pytanie, przytoczę odpowiedzi, jakie już zostały udzielone na pytania podobnie, choć nie identycznie, sformułowane. Kategoria stawania-się-kobietą była bowiem krytykowana przez teoretyczki feministyczne (Jardine 2000). Powodem krytyki był brak miejsca dla rzeczywistych kobiet w deleuzjańskim eksperymencie. Jako że kobiecość, w kontakt z którą wchodzi podmiot, ma charakter molekularny, cały proces obywa się znakomicie bez obecności molowego kobiecego podmiotu. Nie mamy więc do czynienia ze wspólnym stawaniem się dwóch podmiotów, ale ze stawaniem się jednego molowego podmiotu (w domyśle: męskiego), "zarażającego się" krążącym w nieokreślonej przestrzeni wirusem molekularnej kobiecości. To, czym staje się podmiot, nie musi istnieć. Jak zauważają Deleuze i Guattari w odniesieniu do stawania-się-zwierzęciem:

Stawanie-się zwierzęciem istoty ludzkiej jest realne, nawet jeśli zwierzę, którym staje się człowiek, takie nie jest; a stawanie się innym zwierzęcia jest realne, nawet jeśli to coś innego, czym staje się zwierzę, takie nie jest [...]. (Deleuze, Guattari 2008: 262).

W dodatku problematyczny jest status kobiecego podmiotu i - ogólniej - podmiotu należącego do mniejszości jako ewentualnego podmiotu stawania się. Jeśli bowiem kobiety, zgodnie ze stwierdzeniem Deleuze'a i Guattariego, mają również stać się kobietami, oznacza to, że mogą się nimi stać tylko zajmując pozycję neutralnego (męskiego) podmiotu. Jak zauważa Nicole Shukin, podsumowując ten nurt krytyki, perspektywa podmiotu większościowego jest jedyną dostępną na gruncie teorii stawania się. Mniejszości funkcjonują tu wyłącznie jako środek stawania-się-innym

${ }^{6}$ W oryginale "valency" - w językoznawstwie zdolność wyrazów do stwarzania powiązań syntaktycznych. w chemii (choć w języku angielskim stosuje się raczej termin „valence”) wartościowość określa ilość wiązań chemicznych pierwiastka, umożliwiających łączenie się z innymi pierwiastkami. w tym kontekście "valency” ma, jak się zdaje, konotować ogólną zdolność do tworzenia powiązań. 
większościowego (zachodniego, męskiego, ludzkiego) podmiotu. Deleuze, krytykujący Levi-Straussa za wprowadzenie opozycji surowe-gotowane i za modernistyczną nostalgię za zewnętrzem kultury, sam popada w "etnograficzną" fascynację tym, co "surowe”: podczas gdy molekularna kobiecość jest egzotycznym nośnikiem deterytorializacji, molowa kobiecość nie interesuje Deleuze'a, nie istnieje dla niego jako problem (Shukin).

Z drugiej strony pojęcie molekularnej kobiecości jest postrzegane jako potencjalnie inspirujące dla teorii queer i nurtów feminizmu oraz gender studies dążących do zdestabilizowania kategorii płci (Grosz 2002). Na ile zatem pojęcie stawania się może być inspirujące dla teorii feministycznej i queer, a na ile usprawiedliwia zarzuty Jardine czy Shukin?

Sami autorzy Anti-Oedipus: Capitalism and Schizophrenia wydają się potwierdzać zarzuty: „W pewnym sensie podmiot stawania się jest zawsze "człowiekiem/mężczyzną", ale tylko wtedy, kiedy wkracza w stawanie-się-mniejszościowym, które odrywa go od jego istotowej tożsamości" (Deleuze, Guattari 2008: 321).

Linia rozumowania wydaje się przebiegać następująco: Deleuze i Guattari stwierdzają, że to, czym staje się podmiot, nie musi mieć molowego istnienia. Jeśli natomiast je ma (przypadek rzeczywistych, molowych kobiet, które też "muszą stać się kobietami"), zostaje ono automatycznie usytuowane w pozycji podmiotu potencjalnie zdolnego wkroczyć na drogę stawania się - a do tego zdolny jest tylko podmiot większościowy. Wydaje się więc, że filozofowie implikują tu, iż kobiety mają

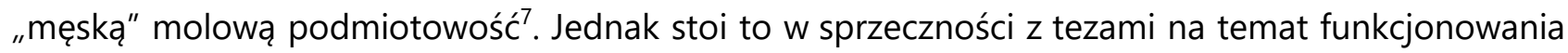
pola społecznego zorganizowanego zgodnie z logiką większościowości. Organizacja ta zakłada hierarchię, która sytuuje pewne molowe podmioty - kobiety, ludzi rasy innej niż biała - w pozycji innych, odbiegających od standardu podmiotowości. Postulat stawania-się-innym/mniejszościowym odniesiony do tych podmiotów wydaje się nie mieć sensu. Tylko człowiek-mężczyzna może stać-się-mniejszościowym; droga ta jest zatem zamknięta dla molowych mniejszości, które całkowicie znajdują się poza nawiasem, pozbawione możliwości eksperymentowania ze swoja podmiotowością.

Aby jednak ostatecznie rozstrzygnąć te kwestię, należy wziąć w nawias fallogocentryczne czy antropocentryczne przykłady i zrekonstruować wewnętrzną strukturę stawania się. Rekonstrukcja ta, choć może sprawiać wrażenie zbędnej pedanterii, jest absolutnie kluczowa - pozwoli bowiem pokazać, że stawanie się dopuszcza jako swój podmiot jedynie „większościowy wzorzec" - podmiot większościowy w znaczeniu molowym.

Stawanie się to przypadek deterytorializacji. Strukturę i funkcjonowanie prostej i złożonej (podwójnej) deterytorializacji określa osiem twierdzeń - "maszynowych tez" znajdujących się w a Thousand Plateaus (Deleuze, Guattari 2008: 193-194, 338) . Dla nas najistotniejsze będzie pięć z nich:

${ }^{7}$ W ten sposób interpretuje ten wątek Buchanan (rozmowa z lipca 2010). 
Deterytorializacja prosta:

Twierdzenie 1: nigdy nie deterytorializuje się samotnie; zawsze istnieją co najmniej dwa terminy [...] Każdy z dwu terminów reterytorializuje się na tym drugim. [...] Istnieje zatem cały system poziomych i dopełniających się reterytorializacji. [...] (pierwszy system [J. B.]).

Twierdzenie 3: [...] najmniej zdeterytorializowany element reterytorializuje się na elemencie najbardziej zdeterytorializowanym. To miejsce, w którym pojawia się drugi system reterytorializacji, pionowy system biegnący od dołu do góry (drugi system [J. B.]).

$\rightarrow$ Deterytorializacja podwójna (stawanie się):

Twierdzenie 5: deterytorializacja jest zawsze podwójna, ponieważ zakłada współistnienie zmiennej większej i zmiennej mniejszej w równoczesnym stawaniu się (dwa określenia stawania się nie zamieniają się miejscami, nie ma między nimi relacji utożsamienia, zamiast tego zostają wciągnięte do asymetrycznego bloku, w obrębie którego oba zmieniają się w tym samym stopniu i który konstytuuje strefę ich bliskości.

Twierdzenie 6: w obrębie niesymetrycznej podwójnej deterytorializacji możliwe jest wyróżnienie siły deterytorializującej i siły deterytorializowanej, nawet jeśli ta sama siła przeskakuje od jednej wartości do drugiej w zależności od rozważanego "momentu" czy aspektu; co więcej, to najmniej zdeterytorializowany element wyzwala deterytorializację elementu najbardziej zdeterytorializowanego [...]

Twierdzenie 7: element deterytorializujący odgrywa względną rolę wyrazu, a element deterytorializowany względną rolę treści [...]

Mamy do czynienia z dwoma typami deterytorializacji: prostą i złożoną (stawanie się to właśnie deterytorializacja złożona, i to ona głównie nas tu interesuje). Istnieją także dwa systemy deterytorializacji: poziomy i pionowy. System pierwszy, poziomy (tw. 1), zakłada istnienie dwóch określeń, podczas gdy system drugi, pionowy, przypisuje im odmienne funkcje. W obrębie deterytorializacji prostej zróżnicowanie funkcji zostaje wprowadzone w twierdzeniu 3, wprowadzającym drugi, pionowy system; w obrębie deterytorializacji złożonej zróżnicowanie to pojawia się już u samych podstaw, w twierdzeniu 5, dotyczącym systemu pierwszego, poziomego. Jest to możliwe, ponieważ określenia nie reterytorializują się tutaj jedno na drugim, jak ma to miejsce w deterytorializacji prostej. Możemy dostrzec, że twierdzenia 5 i 6 powtarzają i potwierdzają treść twierdzeń 1 i 3 - czynią to jednak na innym poziomie, zwiększając złożoność i precyzję funkcjonowania całego systemu. Twierdzenie 5 wprowadza rozróżnienie określeń porwanych przez ruch stawania się: wykluczona zostaje możliwość symetrii, płynności czy wymienności tych funkcji. Twierdzenie 6 precyzuje specjalizację funkcji tych określeń: to najmniej zdeterytorializowany (a więc większościowy, najbliższy centrum) element jest podmiotem deterytorializacji; element najbardziej zdeterytorializowany może 
pełnić tylko funkcję środka "określenia mniejszego" w jego stawaniu się. Pojęcia "najbardziej zdeterytorializowany" i „najmniej zdeterytorializowany” są oczywiście względne i zależą od danych ram odniesienia konkretnego procesu stawania się. Jednak twierdzenie o względności jest w gruncie rzeczy dość zwodnicze, skoro owe ramy odniesienia tworzy najczęściej większościowy standard. W przypadku stawania-się-mniejszościowym (kobietą, dzieckiem, zwierzęciem) termin większy stanowi sam ten standard - Człowiek/Meżczyzna/Biały jako element zdecydowanie najmniej zdeterytorializowany; jego liczni inni rozkładają się w różnych miejscach na skali deterytorializacji. Twierdzenie 6 przewiduje wprawdzie możliwość zamiany ról, ale nie rezygnację z samego rozróżnienia funkcji. Jedynym miejscem, w którym specjalizacja funkcji nie zostaje wzięta pod uwagę, jest najbardziej rudymentarne twierdzenie 1 - nie może ono jednak funkcjonować w oderwaniu od pozostałych twierdzeń. Zgodnie z twierdzeniem 7 termin mniejszy jest wyrazem - czyli swego rodzaju formą ${ }^{8}$ - jaką przybiera stawanie się treści - określenia większego. Fakt, że oba określenia zmieniają się w takim samym stopniu (tw. 5), nie świadczy przeciw temu - Deleuze i Guattari podkreślają przecież, że zmiany nie mają analogicznego charakteru. Termin mniejszy zmienia się w takim samym stopniu, ale w całkowicie różny sposób - nie jako podmiot, ale jako środek stawania się. Samo rozróżnienie funkcji wskazuje, że asymetria - podmiot i traktowany instrumentalnie środek - jest trwałą i niezbywalną cechą stawania się.

Można więc przyjąć, że blok stawania się jest ustrukturyzowany w następujący sposób:

\section{Blok stawania się:}

Podmiot

Zmienna większa

Element najmniej zdeterytorializowany

Treść

(„Człowiek")
Medium

Zmienna mniejsza

Element najbardziej deterytorializujacy

Wyraz

(Inny/a/e)

Stawanie się ma precyzyjnie określoną strukturę; co więcej, ta struktura jest jednoznacznie hierarchiczna.

Przypadki stawania się, mające miejsce w ramach odniesienia innych niż pole społeczne, posiadają nieco inny charakter. Należą do nich słynne przykłady osy i orchidei oraz kota i pawiana z "Kłącza” (Deleuze, Guattari, 1988). W pierwszym przypadku pewien gatunek orchidei naśladuje wygląd samicy osy i wytwarza feromony, przywabiające samca osy, który "kopuluje” z kwiatem - a wtedy przyczepia się do niego pyłek orchidei, który przenosi on na następny kwiat. W drugim przypadku wirus, przenosząc się z jednego nosiciela (pawiana) na drugiego (kota), zachowuje część informacji genetycznej pierwszego nosiciela (Deleuze, Guattari 1988: 225-226). Struktura bloku stawania się dla drugiego z przykładów wygląda następująco:

8 Pomijam tu sposób, w jaki Deleuze i Guattari starają się wykroczyć poza dychotomię formy i materii, wprowadzając dychotomię wyrazu i treści. 
kot

Deterytorializowane

Zmienna większa

Treść pawian

Deterytorializujące

Zmienna mniejsza

Wyraz

Struktura stawania się jest tu więc dość podobna do struktury stawania-się-mniejszościowym; jeden termin jest obiektem/podmiotem stawania się (deterytorializacji), drugi czynnikiem deterytorializującym. Różnica polega na tym, że oba określenia mają, oprócz wymiaru molekularnego odpowiedzialnego za deterytorializację, autonomiczne istnienie molowe: mówimy o realnych kotach i pawianach. Oba molowe byty podlegają transformacji (zarażeniu wirusem), stąd - mimo, że struktura pozostaje niezmieniona - mamy wrażenie większej symetrii czy równowagi. W przypadku osy i orchidei mamy do czynienia z prawdziwą wzajemnością: każde z określeń zostaje jednocześnie zdeterytorializowane i zreterytorializowane, a więc utwierdzone w swoim molowym istnieniu przez drugi termin:

Orchidea deterytorializuje się tworząc obraz, odbitkę osy; ale osa reterytorializuje się w tym obrazie. Osa deterytorializuje się jednak, sama stając się częścią aparatu reprodukcji orchidei; ale reterytorializuje orchideę przenosząc pyłek (Deleuze, Guattari 1988: 225)

Dlatego Deleuze i Guattari mogą określić ten przypadek jako stawanie-się-osą orchidei, stawaniesię-orchideą osy (Deleuze, Guattari 1988: 225).

Skąd te różnice? Można odnieść wrażenie, że rozróżnienie funkcji i podział na termin większy i mniejszy zaczynają być równoznaczne z utratą molowego istnienia przez termin mniejszy wtedy, kiedy w miejscu terminu większego pojawia się Człowiek jako standard większościowy pola społecznego. Nawet w procesie tracenia swojej tożsamości podporządkowuje on Innych swoim potrzebom do tego stopnia, że tracą oni zdolność do samodzielnej egzystencji - i samodzielnej dęterytorializacji.

Można by, parafrazując Gayatri Spivak (Spivak, 2011), zapytać: czy Inny-termin mniejszy potrafi mówić? Odpowiedź udzielona na gruncie ortodoksyjnego deleuzjanizmu musiałaby brzmieć: nie. Termin mniejszy nie mówi; nie tylko nie musi, ale nie może istnieć inaczej niż wyłącznie w wymiarze molekularnym. (Molekularne) zwierzę staje się „czymś innym” wyłącznie po to, żeby człowiek mógł stać się zwierzęciem; w tym przypadku asymetria jest najbardziej widoczna i uderza również w doborze przykładów, który stał się powodem krytycznych uwag Donny Haraway w When Species Meet (Haraway 2008).

Tekst Melville'a, dotyczący stawania się, stanowi również narracyjny acting out jego strukturalnych ograniczeń. Świadectwem tego jest fakt, że napisanie tej historii z perspektywy Bartleby'ego wydaje się dosłownie nie do pomyślenia. Możemy wprawdzie pomyśleć: i bogu narracji za to dzięki, historia opowiedziana z perspektywy Bartleby'ego odebrałaby nam przyjemność obcowania z enigmą 
- ale zastanówmy się, czy na pewno apelowanie do jakiegokolwiek boga jest tu na miejscu. Wyłączność perspektywy adwokata-narratora sprawia, że stawanie-się-mniejszościowym zostaje nam ukazane jako wyłącznie jego przedsięwzięcie, dla którego Bartleby jest tylko pretekstem. Istotny jest nie tyle fakt, że chce on wycofać się z paktu zawartego z Bartlebym, ale to, że od samego początku traktował go jak środek dla własnego (prawda, że podejmowanego nieświadomie) wysiłku oddalenia się od większościowego centrum. Bartleby nie jest niczym więcej niż przestrzenią projekcji narratora, punktem zaczepienia dla jego eksperymentu z podmiotowością. Dlatego nie wiemy o nim nic i niemożliwe jest, żebyśmy mogli cokolwiek wiedzieć. W tekście obecne są jednak pewne dyskretne symptomy świadczące o możliwości innego postawienia sprawy. Bartleby, w odpowiedzi na wezwanie narratora do wyprowadzenia się z kancelarii, w której zamieszkał, mówi: „Wolałbym pana nie opuszczać" (Melville 2009: 43). Wypowiedź ta wpasowuje się w logikę "wirusowego" dyskursu "wolałbym nie" - ale jednocześnie sygnalizuje, że Bartleby ma własne - nawet jeśli tylko negatywne - preferencje, odrębne i niezależne od preferencji, jaką jest stawanie się narratoraokreślenia większego.

W myśl odczytania, które chciałabym zaproponować, J. M. Coetzee w Życiu i czasach Michaela K. podąża tropem tych właśnie symptomów ${ }^{9}$. Pierwsza i trzecia część opisują, w trzeciej osobie, tułaczkę tytułowego bohatera, pochwyconego w tryby urządzenia wojny domowej - połączenia dyscyplinarnych regulacji i chaotycznej przemocy. Pierwszoosobowym narratorem II części jest natomiast lekarz z obozu jenieckiego, gdzie Michael K. trafia, oskarżony o udzielanie pomocy partyzantom. Pojawiają się tu wszystkie cechy stawania się, które Deleuze odnajduje w Bartlebym - są jednak podkreślone, uwydatnione i w ten sposób de facto zdekonstruowane. Należy do nich asymetria, wyłączność perspektywy narratora - terminu większego, normalnego podmiotu. Spotkanie z Michaelem K. wytrąca lekarza z równowagi: „Zanim się zjawiłeś, wszystko było ze mną w porządku. Byłem szczęśliwy, o tyle szczęśliwy, o ile można w takim miejscu" (Coetzee 2007: 159).

Proces deterytorializacji zostaje tym samym rozpoczęty: "[...]poświęcam mu zbyt wiele uwagi" (Coetzee, 2007: 145) - stwierdza narrator, który kieruje się nie tylko potrzebą udzielenia pomocy i uratowania pacjenta, który uparcie nie chce jeść, ale także osobliwym przymusem zrozumienia, wzbudzonym przez poczucie istnienia tajemnicy, do przeniknięcia której czuje się powołany: „Najbardziej tajemniczy z tajemniczych, tak tajemniczy, że graniczy to z cudem” (Coetzee 2007: 151) mówi o Michaelu K., dostrzegając w nim istotę spoza kultury, historii, wreszcie spoza samego człowieczeństwa:

Chyba jest nie całkiem z tego świata [...]. Jest jak kamień, jak kamyk, który leżał sobie spokojnie, nikomu nie wadząc, od zarania czasu, a teraz ktoś go nagle podniósł i przerzuca niedbale z ręki do ręki [...] Przelatuje przez te zakłady, obozy, szpitale i Bóg wie co jeszcze niczym kamień. Przez kiszki wojny. Nie rodząca, nie

\footnotetext{
${ }^{9}$ Przemiany, którym podlega Michael K., interpretował wcześniej w kategoriach stawania się Jean-Paul Engélibert. Pomija on jednak kwestię „dwuczłonowości" struktury stawania się, traktując je jak proces posiadający tylko jeden podmiot (którym miałby być, dość bezproblemowo, tytułowy bohater). Dlatego nie zwraca szczególnej uwagi na relację Michael K. - lekarz. Zob. J.-P. Engélibert, Jak Michael K. stawat się niedostrzegalnym. „Literatura mniejsza” i opór (2013). Tekst Engéliberta jest także dostępny online: http://www.praktykateoretyczna.pl.
} 
narodzona istota. W gruncie rzeczy nie umiem myśleć o nim jak o mężczyźnie, chociaż wedle wszelkich znaków jest starszy ode mnie. (Coetzee 2007: 138, 143144)

Lekarz, przytłoczony poczuciem bezsensu wojny domowej, jest zafascynowany tym, że jego osobliwy pacjent funkcjonuje poza podziałami politycznymi, normami społecznymi, nawet poza wszechobecnym w wojennej rzeczywistości dążeniem do przeżycia za wszelką cenę; ucieczki z obozu i odmowę jedzenia klasyfikuje jako niemal fizjologiczne uzależnienie od wolności: „Nie umrę. [...] ja tylko nie mogę tutaj jeść. To obozowe jedzenie. Nie mogę tego jeść" - mówi Michael K. „Może jada tylko chleb wolności" (Coetzee 2007: 156) - komentuje narrator. Robi to w zasadzie trafnie - jednak sama elokwencja narratora sprawia, że liczne wyjaśnienia, które stara się wypracować, w dziwny sposób omijają fenomen Michaela K. Stawanie się w wykonaniu narratora to właściwie nic innego, jak seria prób wyjaśnienia, znalezienia właściwej definicji, wytworzenia kategorii, które miałyby zaklasyfikować, zreterytorializować anomalię, jaką jest Michael K. Wykorzystuje on w tym celu między innymi kod edypalny. Uznaje bowiem za kluczową relację swojego pacjenta z matką, która umarła w trakcie (opisanej w części pierwszej) ucieczki z miasta na farmę - miejsce jej urodzenia. Narrator uznaje martwą matkę za Nemezis, prześladującą więźnia (Coetzee 2007: 159-160), co wydaje się w dużej mierze spekulacją pozbawioną podstaw. Jednocześnie - co pozostaje w sprzeczności z powyższa strategią - usiłuje nadać sens temu, co definiuje jako aspołeczność i nieludzkość Michaela, jego podobieństwo do bytów nieożywionych, umieszczając go poza historią i społeczeństwem, definiując jako część "natury” lub relikt czasów prehistorycznych (Coetzee 2007: 161). Z tą kwestią związany jest problem rasy - czy raczej znacząca nieobecność tego problemu w tekście. Akcja Życia i czasów... toczy się w RPA, choć, z racji przypowieściowej konwencji, odniesienia do rzeczywistych wydarzeń i realiów społecznych pozostają zredukowane i abstrakcyjne. Rasa zostaje dosłownie wymazana z tekstu; o kolorze skóry bohaterów możemy wnioskować w oparciu o „zewnątrztekstową" wiedzę (ale czy tekst ma dokładnie określone granice?) jedynie na podstawie ich statusu społecznego ${ }^{10}$. Niezdolność do dostrzeżenia rasy/koloru jako sytemu społecznej stratyfikacji jest istotnym symptomem porażki stawania się w wykonaniu narratora. Narrator postrzega Michaela K. przez pryzmat abstrakcyjnej „aspołeczności”, pozostaje natomiast ślepy na konkretną społeczną hierarchię, dzięki której dysponuje przewagą. W relacji z pacjentem/więźniem-czarnym hierarchia ta stawia lekarza-białego w pozycji podmiotu posiadającego monopol na mówienie, tworzenie spójnej i miarodajnej narracji.

Wspólną cechą usiłowań lekarza jest więc nacisk na ujęcie doświadczenia pacjenta w spójną narrację. "Nie za dobrze sobie radzę ze słowami" - stwierdza Michael K., ale to nie powstrzymuje narratora (Coetzee 2007: 147). Podczas przesłuchania próbuje zmusić więźnia do mówienia nie tylko w imieniu władzy, ale także w swoim imieniu, by stało się zadość konieczności poznania tajemnicy, ujęcia jej w słowa: „Opowiedz panu majorowi o swojej matce [...] Ty masz swoją historię, a my ją chcemy usłyszeć [...] opowiedz swoją historię! My słuchamy!" (Coetzee 2007: 148-149).

10 Wymazanie nie jest jednak kompletne: podczas przyjmowania do obozu Michael K. zostaje oznaczony jako "CM", co stanowi skrót od coloured male. Por. M. Kościańczuk, Ucieczka od słowa i pewien rodzaj prawdy (2013), s. 245. 
Żądanie to musi spotkać się jednak z ostateczną frustracją: „nie próbuj wyciągnąć z niego jakiejś historii, on naprawdę nie ma żadnej" (Coetzee, 2007: 150). Mimo to narrator części drugiej nie uczy się niczego: rozstajemy się z nim, kiedy - po ucieczce Michaela K. Z obozu - monologuje na temat wyjątkowości swojej roli: „Ja jeden mogę cię uratować. Ja jeden widzę w tobie niezwykłą istotę, którą jesteś" (Coetzee 2007: 161). Jest najwyraźniej pewien, że tak naprawdę liczy się nie sama niezwykłość, ale ten, kto potrafi ją dostrzec i docenić. Tymczasem Michael K. niczego od niego nie chce - ani troski, ani „zrozumienia”; ostatecznie ucieka z obozu tylko po to, by dalej wieść egzystencję na granicy śmierci.

Usiłowania narratora od początku są skazane na porażkę; tak naprawdę nie jest on w stanie podążyć drogą stawania się. Jego deterytorializacja jest w ostatecznym rozrachunku minimalna, ponieważ zawsze równoważy ją on reterytorializacjami. W ten sposób zatrzymuje proces stawania się. Podobnie jak w przypadku Bartleby'ego (tylko z większą wyrazistością), tekst tematyzuje wady asymetrii między terminem większym i mniejszym stawania się, fakt, że uniemożliwia ona stawanie sięmniejszościowym. Jeśli można pokusić się o uogólnienie lekcji tekstu, porażka jest wbudowana strukturalnie w proces stawania-się-mniejszościowym, który nigdy nie jest stawaniem-się-z ${ }^{11}$, uznaniem autonomii terminu mniejszego, faktu, że mogłoby ono być zaangażowane we własny proces deterytorializacji.

Coetzee dekonstruuje zatem asymetrię stawania-się-mniejszościowym w części drugiej. W pozostałych częściach tekstu dokonuje jednak jeszcze czegoś innego: można powiedzieć, że próbuje opowiedzieć historię z punktu widzenia określenia mniejszego. W ten sposób przekształca za pomocą środków literackich pojęcie stawania-się-mniejszościowym. Nie jest to łatwe zadanie; chodzi bowiem o zdanie sprawy z doświadczenia, które wymyka się słowom i któremu nie pomaga elokwencja (o czym świadczy fakt, że próby ujęcia go w słowa w części drugiej przez lekarza wydają się tak bardzo nieadekwatne). Jak opowiedzieć historię o losach kogoś, kto "nie ma żadnej historii"? Zdystansowana, surowa trzecioosobowa narracja wydaje się wyborem lepszym niż narracja pierwszoosobowa. Zdaje ona sprawę, w chłodny i niezaangażowany sposób, z procesu postępującego ogołocenia, redukcji. Proces ten jest wynikiem zetknięcia się egzystencji (już ograniczonej i ubogiej) Michaela K. Z urządzeniem wojennym, jednocześnie deterytorializujacym społeczeństwo (wymuszającym porzucanie dotychczasowego trybu życia i miejsc zamieszkania) i próbującym je kodować (system przepustek i obozów). Kiedy umiera jego matka, bohater chce znaleźć farmę, na której się urodziła, żeby rozsypać tam jej prochy - w końcu dociera tam, ale nie wiadomo do końca, czy to właściwe miejsce (Coetzee, 2007: 126). Nie ma to jednak większego znaczenia; farma jest nie tyle miejscem edypalnego regresu, ale abstrakcyjnym terytorium, niezależnym - choć niezależność ta okazuje się bardzo krucha - od wojennego porządku. Terytorium, które próbuje stworzyć Michael K., jest od samego początku bardzo ograniczone. Na farmie próbuje uprawiać ogród, ale nie zajmuje domu, i to nie tylko ze względu na ostrożność. W końcu, przed schwytaniem, mieszka w jamie wykopanej w ziemi i śpi przez większość czasu - krańcowo osłabiony, traci kontakt ze światem zewnętrznym i własnym ciałem, doświadcza spowolnienia, swoistej inwolucji procesów życiowych:

\footnotetext{
11 Termin stworzony przez Donnę Haraway.
} 
Przychodziły długie godziny, kiedy leżał w tępym odrętwieniu, zbyt zmęczony, by się otrząsnąc ze snu. Czuł, jak wszystkie procesy zachodzące w ciele przebiegają coraz wolniej. Zapominasz o oddychaniu - mówił sobie, a mimo to nadal nie oddychał (Coetzee 2007: 127-128)

Ten graniczny stan nie jest oczywiście zamierzony. To, co dzieje się z bohaterem, nie jest skutkiem jego działań intencjonalnych, ale dynamiki autonomicznego procesu, zmierzającego w stronę życia, które niewiele dzieli od śmierci - tylko taka redukcja gwarantuje bowiem niezależność tego życia. Dlatego Michael K. wciąż ucieka, wymykając się wojennym regulacjom, nie mogąc dostosować się do obozowego reżimu - nawet jeśli poddanie się mu oznaczałoby możliwość odzyskania zdrowia i sił.

Ta gra deterytorializacji i reterytorializacji nie jest jednak stawaniem się ${ }^{12}$. W dodatku okoliczności, w jakich ma miejsce, sprawiają, że ostatecznie jest destrukcyjna; utrzymywanie niezależności jest możliwe tylko kosztem krańcowej redukcji życia. Podmiot, który z racji swojego nieprzystosowania, oddalenia od centrum ekonomicznej, społecznej i symbolicznej władzy jest predestynowany do pełnienia funkcji terminu mniejszego w cudzym stawaniu się, może tylko zniknąć - ostatecznie jego molowe istnienie jest tylko przeszkodą, jako że termin mniejszy powinien istnieć tylko w wymiarze molekularnym...

Wobec faktu, że stawanie-się-mniejszościowym jest asymetryczne, a jego określeniem większym może być tylko podmiot większościowy, istotne byłoby wypracowanie takiego pojęcia stawania-sięmniejszościowym, które nie zakładałoby zróżnicowania funkcji, podziału na termin większy i termin mniejszy. Pojęcie stawania się z Kłącza oferuje pewne obiecujące wskazówki, w którą stronę należałoby podążyć - nie jest to jednak stawanie-się-mniejszościowym, nie dotyczy przekształcania większościowego standardu. Termin mniejszy wciąż czeka na pojęcie stawania się bardziej dostosowane do swoich potrzeb.

\section{Bibliografia}

Agamben, Giorgio. 2009. Bartleby, czyli o przypadkowości. Tłum. S. Królak. W: Melville, Herman. Kopista Bartleby. Historia z Wall Street. Tłum. A. Szostkiewicz. Warszawa: Sic!, s. 61-104.

Buchanan, Ian. 2000. Deleuzism. A Metacommentary. Duke University Press: Durham.

Coetzee, John M. 2007. Życie i czasy Michaela K. Tłum. M. Konikowska. Warszawa: Znak/Axel Springer Polska.

Deleuze, Gilles. 2009. Bartleby albo formuła. Tłum. G. Jankowicz. W: Melville, Herman. Kopista Bartleby. Historia z Wall Street. Tłum. A. Szostkiewicz. Warszawa: Sic!, s. 105-155.

Deleuze, Gilles, Guattari, Felix. 1984. Anti-Oedipus: Capitalism and Schizophrenia. Tłum. R. Hurley, M. Seem, H. R. Lane. London: The Athlone Press.

12 Dla Engéliberta, przeciwnie, epizod na farmie jest kluczowy; por. J.-P. Engélibert, s. 181-183. 
- - -. A Thousand Plateaus. Capitalism and Schizophrenia. 2008. Tłum. B. Massumi. London:

Continuum.

- - -. 1988. Kłącze. Tłum. B. Banasiak. „Colloquia Communia” 1-3.

Hardt, Michael, Negri, Antonio. 2005. Imperium. Tłum. A. Kołbaniuk, S. Ślusarski. Warszawa: W. A. B.

Engélibert, Jean-Paul. 2013. Jak Michael K. stawat się niedostrzegalnym. "Literatura mniejsza" i opór. W: (red.) Jakubowski, Piotr, Jankowska Małgorzata et al. Wielcy artyści ucieczek. Kraków: ha!art, s. $173-185$.

Haraway, Donna. 2008. When Species Meet. Minneapolis: University of Minnesota Press.

Jardine, Alice. 1984. Woman in Limbo: Deleuze and His (Br)others. "SubStance” 44/45, s. 46-60.

Olkowski, Dorothea. 2008. After Alice: Alice and the Dry Tail. W: (red.) Colebrook, Claire, Weinstein, Jami. Deleuze and Gender. Edinburgh: Edinburgh University Press, s. 107-122.

Kościańczuk, Marcela. Ucieczka od słowa i pewien rodzaj prawdy. W: (red.) Jakubowski, Piotr, Jankowska Małgorzata et al. Wielcy artyści ucieczek. Kraków: ha!art, s. 241-253.

Rancière, Jacques. 2004. The Flesh of Words: The Politics of Writing. Tłum. C. Mandell, Stanford: Stanford University Press.

Shukin, Nicole. 2000. Deleuze and Feminism: Involuntary Regulators and Affective Inhibitors. W: (red.) Buchanan, Ian, Colebrook, Claire. Deleuze and Feminist Theory. Edinburgh: Edinburgh University Press, s. 144-155.

Žižek, Slavoj. 2006. Notes Towards a Politics of Bartleby. "Comparative American Studies" 4, s. 375394.

Spivak, Gayatri Ch. 2011. Czy podporządkowani inni moga przemówić?. Tłum. E. Majewska, „Krytyka Polityczna", s. 24-25. 